Article

\title{
Economic Complexity and the Mediating Effects of Income Inequality: Reaching Sustainable Development in Developing Countries
}

\author{
Emilie Le Caous ${ }^{1, *}$ and Fenghueih Huarng ${ }^{2}$ \\ 1 College of Business, Southern Taiwan University of Science and Technology (STUST), No.1, Nantai Street, \\ Yongkang District, Tainan 71005, Taiwan \\ 2 Department of Business Administration, Southern Taiwan University of Science and Technology, No.1, \\ Nantai Street, Yongkang District, Tainan 71005, Taiwan; fhhuarng@stust.edu.tw \\ * Correspondence: emilielc@stust.edu.tw; Tel.: +886-983691768
}

Received: 21 January 2020; Accepted: 2 March 2020; Published: 9 March 2020

\begin{abstract}
According to the United Nations Development Program, sustainable development goals are fundamental for attaining a better and more sustainable future for all of us, and are a primary concern today. New indicators, such as the Economic Complexity Index (i.e., ECI), can be used to predict human development index (i.e., HDI). To be defined as a complex economy, a country, through a vast network of individuals, should be able to interlink extensive quantities of relevant knowledge to create diversified products. Political, cultural, and environmental factors should also be included in this model to improve the measurement of human development. This paper aimed to study the relationship between the ECI and HDI and the mediating effects of income inequality among developing countries. Hierarchical linear modeling was used as a statistical tool to analyze 87 developing countries from 1990 to 2017, which also studied the country-level effects of gender inequality and energy consumption. Different year lags were used for more robustness. The results show that human development increased with higher economic complexity. This relationship was, however, partially mediated by income inequality. Country-level predictors, gender inequality, and energy consumption also impacted sustainable development. Finally, it is essential to note that this model cannot be applied to developed economies.
\end{abstract}

Keywords: human development; economic complexity index; income inequality; gender inequality; environmental sustainability; hierarchical linear modeling; HLM

\section{Introduction}

What is development? How can a country develop? Income, in particular the GDP per capita, cannot be considered the only way to measure development. Nations must focus on the way their citizens live their lives and how to improve it. Therefore, human development, which focuses on income, education, and health factors, became fundamental to the study of sustainable development.

To better understand and improve human development, economic, political, cultural, and environmental factors should also be included. The economic complexity index is "the indicator of the composition of a country's productive outputs and the structures that emerge to hold and combine knowledge" [1]. To be defined as a complex economy, a country, through a vast network of individuals, should be able to interlink extensive quantities of relevant knowledge to create diversified products. There are not many studies linking economic complexity and human development. There is an implicit assumption that a country that focuses on innovation and is economically diversified will have greater freedom of choice, capabilities, and well-being [2]. However, economic complexity is not the only factor that may influence human development. We believe that its effects may be mediated by income 
inequality. Regardless of culture, religion, and ideology, people care about inequality. In developing countries, infant mortality rates and female mortality rates are higher in poorer households [3,4]. For those economies, as income inequality decreases, better access to education for lower-income households increases.

Furthermore, economic complexity is a meaningful and negative predictor of income inequality [5]. The productive structure of a country is made up of a broad mix of complex products. To create this vast mix of products, a large scope of occupational choices and a flatter hierarchy of occupational structure are needed. Skills and knowledge are scattered. Furthermore, there is an extended class consciousness. All of these factors decrease income inequality [6]. Over time, economies with a high level of complexity experience a decrease in their level of income inequality [5].

Additionally, in this study, we investigated our belief that gender inequality and environmental sustainability are essential indicators of the level of sustainable development in developing economies. Energy and gender are linked and impact human development in developing countries [7]. In those nations, food processing, water, and firewood collection is commonly a female-gendered role. Carrying fuelwood is harmful to a woman's health and safety since it creates back injuries due to the heavy loads, and it deprives them of education.

The purpose of this study was to examine the effects of economic complexity on human development in developing countries, and whether these effects were mediated by income inequality. Furthermore, we were interested in the country-level impacts of gender inequality and energy consumption. To analyze the yearly and country effects of different variables on sustainable development, we used hierarchical linear modeling (HLM) as our statistical tool. The data was taken from 60 developing countries from 1990 to 2017. We also used different year lags to obtain more robust results.

This article contributes to the field of research by integrating not only political factors to understand human development, but also a new economic indicator, namely the economic complexity index, as well as cultural and environmental indicators. This study, which was based on quantitative results, provides comprehensive empirical findings, and digs further into the mediated effects of income inequality, as suggested by Ferraz et al. [8]. Furthermore, we found that a different model should be created when analyzing human development in developed countries. Finally, this article is an extension of two papers that we presented at the 2019 International Conference on Design with Intelligence and Humanity (ICDIH) at Yunlin University, Taiwan, in November 2019 [9], and at the 15th International Conference on Knowledge-Based Economy and Global Management in Southern Taiwan University of Science and Technology in November 2019.

This paper is structured as follows: in the next section, we discuss the relationship between economic complexity, income inequality, and human development. Next, we present our data and the hierarchical linear modeling (HLM) methodology. In Section 4, we analyze and interpret the statistical results. Finally, we discuss our findings and the possibilities of future research.

\section{Literature Review}

\subsection{Human Development}

The 17 sustainable development goals provide a basis for reaching a better and more sustainable future for all of us (the United Nations Development Program, UNDP). These 17 goals are complementary and the United Nations wishes to reach them by 2030. Sustainability is one of the essential backbones of human development. The remaining pillars are equity, productivity, empowerment, cooperation, and security [10]. To achieve sustainable human development, we must encourage the well-being of individuals. Even though life expectancy has significantly improved, "the proportion of mothers that do not survive childbirth, as compared to those who do in developing regions, is still 14 times higher than in developed regions," showing the need for enhancement regarding health standards in those countries (UNDP). Education also plays an integral part in sustainable 
development. In developing countries, "children of educated mothers-even mothers with only primary schooling-are more likely to survive than children of mothers with no education" (UNDP). Therefore, the fourth sustainable development goal, quality education, is as important as good health. Education is the underlying structure that gives rise to sustainable development due to its impact on the quality of life, but also through its capacity to provide individuals with the tools needed to create innovative solutions for the world's challenges. Even though significant progress over the past decade regarding access to education has been made, more efforts regarding universal education goals, such as targeting equality at all levels (and not only at the primary level) of education between men and women, need to be made.

To contribute to the development of a country and to be able to make decisions, having access to education, health, accommodation, and income is important for individuals [11]. The goal of humanity is to implement an environment that enhances individual freedom, but also improve the range of choices associated with having a longer and healthier life [12,13]. Human Development is "the process of expanding individual freedom" [8]. It focuses on human life rather than the economy. It is about enhancing the richness of an individual's opportunities and choices (UNDP). The main element of human development is the freedom of agency, which gives individuals the autonomy to live their life the way they want, along with the freedom of well-being. By being healthier, more knowledgeable, creative, and having access to resources, people can achieve a decent standard of living.

One of the most used databases is the Human Development Index (HDI) [14]. It is the most widespread substitute to the GDP per capita due to its ability to measure not only income, but also social outcomes, such as life expectancy, adult literacy, and gross educational enrollment [2]. One of the limitations of this index is that there is no historical data at the yearly level [2], and it competes with other sources, such as the World Bank [15]. However, since its creation, every time the HDI received criticism, the UNDP responded with improvements of its index [16].

The HDI was created by Mahbub-ul-Haq, a Pakistani economist, then improved by Amartya Sen, an Indian economist, and has been used by many researchers since then. The HDI integrates the capability approach, which was created by Amartya Sen, which is used to comprehend human well-being. The key in this approach is that decent standards of living, which represent the ends, should be more important than the means, such as income per capita. Health, education, and goods are measurements of the ends of development. If individuals are granted better access to those key indicators, but also to other capabilities, they can reach a particular state of well-being [16]. The HDI is "a statistical tool used to measure countries' overall achievements in its social and economic dimensions" [10]. It uses four indicators to measure and rank countries: gross national income per capita, life expectancy at birth, average years of schooling, and expected years of schooling. Then, countries are separated into four tiers: very high, high, medium, and low level of development. In this paper, due to methodological concerns, we did not separate countries by their level of human development, and decided to focus on developing countries only.

\subsection{Economic Complexity and Human Development}

\subsubsection{Background}

Since the industrial revolution, industry and the economy have changed in many ways. In the evolution of economic growth, a new production of goods appeared with a change of social actors [17]. The transformation of the productive structure of a country has attracted much interest in the last few decades. Most literature reviews highlight the purpose of structural change and economic diversification for long term growth [18]. Even so, few researchers asked whether the complexity of products that economies can produce and export predicts the countries' human development and well-being $[2,9,19,20]$.

When studying human development, economic growth is usually the critical indicator taken into consideration. GDP can improve well-being by creating a better quality of life [21]. However, 
both economies with low or high incomes may experience a high life expectancy [22]. Therefore, economic growth is not a synonym for the immediate quality of life. Moreover, economic growth by itself is not enough to comprehend human development. The available knowledge in a country has many impacts: it produces goods, influences economic diversification, and affects jobs.

The productive structure of a country and its diversification of products is more important for human development than economic growth [19]. More complexity means that more knowledge is available. People may improve their capabilities and opportunities if they want to. To accelerate agents' freedom, economic and social aspects need to be included. If people have access to education, health, and basic sanitation, opportunities are easily created.

Nevertheless, to appreciate those opportunities, people should expand their capabilities and functions, which is called "social opportunity" [23]. Countries can transform their produced wealth into human development [24,25]. To do so, they focus on a set of significant operations for agents in society, namely their capabilities. They can also focus on the types of jobs that are essential for human development [19]. Therefore, policymakers should develop conditions for innovation and economic diversification.

Economic complexity became a new hot topic due to its highly predictive role regarding future economic growth, but also regarding social welfare [5]. Countries have to be more complex to be more efficient in creating human development [8]. Economic complexity is the productive structure of a nation [26]. There is more complexity involved in producing and exporting transportation or medical equipment than textiles. A country that has a low complexity is not diversified in the products it ships, and those products usually are not high-tech [25].

\subsubsection{What Is the Economic Complexity Index (ECI)?}

In our economic world, things are made using machines, raw materials, labor, and knowledge. As stated by Ricardo et al. [27], the colossal amount of knowledge, dispersed among different people around the world, is obtainable through the market. Therefore, products play the role of vehicles of knowledge [28].

There are two types of knowledge: explicit and tacit. The problem is that most knowledge is tacit. That is a constraint in the process of growth and development. Indeed, it takes a long time and is harder and more costly to transfer this type of knowledge among people [27]. Consequently, we have to specialize. According to Adam Smith, "the division of labor is the secret of the wealth of nations" [18]. Thus, the market's size plays a crucial role. If the market is big, it has more individuals that can specialize. Therefore, an extended division of labor may be attainable [28]. However, the main point here is not about the quantity of knowledge held, but about the ability for individuals to interact with and interlink that diverse knowledge [27]. In their reinterpretation, Ricardo et al. [27] stated that "the division of labor is what allows us to access the quantity of knowledge that none of us would be able to hold individually." Nowadays, we live in a globalized world, where countries are interconnected to each other through markets. An important question is: if states are interconnected and have the possibility to exploit a global division of labor, why are there differences in GDP per capita? [28].

As we have seen previously, the main reason is related to the capabilities each individual holds. Skills can be classified into different levels: individual, organization, and a network of organizations [1]. To create products, individuals with varying types of knowledge must interact. If this capability set emerges, a complex society can exist and sustain itself [27]. However, even though individuals share their expertise through global markets, not every country has the same set of capabilities. A nation uses the available knowledge that its citizens possess and creates whatever products they can. Particularities, such as property rights, regulations, infrastructures, and specific labor skills, cannot be imported and have to be produced by each country individually [28].

To quantify the competitiveness of countries and the quality of their exported products is the goal of the economic complexity approach. To do so, two different metrics can be used: the fitness-complexity method (FCM) and the method of reflections (MR) [29]. From a bipartite network point of view, 
countries are connected to the products they export, which is represented by international trade data. This interconnectedness in the global market is the basic idea supporting the economic complexity approach. The method of reflection, which is the method used to develop the Economic Complexity Index (ECI), is based on the diversity and ubiquity of countries and products. It was developed by Cesar A. Hidalgo (MIT Media Lab) and Ricardo Hausmann (Harvard University's Kennedy School of Government). The ECI considers the network connectedness of institutional and education quality measures, for example. However, MR has mathematical and conceptual problems [29,30]. Data is available in the Observatory of Economic Complexity. One of the main reasons that countries develop a high level of complexity is related to the competitive advantage they can possess in the global economy. If a marketplace has the aptitude for creating sophisticated goods, this country will probably experience higher returns compared to countries with lesser competences [31]. The method of reflection uses a set of linear iterative equations to measure the complexity of products and countries. In contrast, the fitness-complexity method uses a set of non-linear iterative equations. The MR and FCM are different in two ways: conceptually and mathematically [30]. In a conceptual way, the method of reflection uses a linear approach "between the ubiquity of a product and the competitiveness of its exporters at a given order of iteration," while the FCM focuses on a "highly non-linear relationship between the complexity of products and the fitness of countries producing them" [30]. Furthermore, Tacchella et al. explained that the complexity of a product itself cannot be explained by the fact that a product is developed by a diversified country since most products can be created and exported by highly complex countries. Therefore, the main differences come from the linearity or not of the approach and the diversity of the export basket. Due to the criticism of the ECI, Hidalgo et al. decided to develop the ECI+, which is defined as "the complexity of an economy as the total exports of a country corrected by how difficult it is to export each product and by the size of that country's export economy" [32], and found that it outperforms the FCM and the previous ECI. No method is perfect, and both ECI and FCM were, are, and will be criticized and challenged by others [33,34].

There are not many studies linking the ECI and the HDI. There is an implicit assumption that a country that focuses on innovation and is economically diversified will have a greater freedom of choice, capabilities, and well-being [2]. In the following two subsections, we will criticize this relationship in both positive and negative ways.

\subsubsection{Arguments Supporting the Positive Effect of Economic Diversification on Human Development}

An economy with a diversified productive structure needs a set of capabilities that can adapt to technological change [35]. Through the scope of growth and modernization, a country must implement conditions for innovation, competitiveness, and economic diversification.

Therefore, if a country wishes to reach a higher complexity, it must expand its skills and human capital. A higher educational level is a necessity. Due to advancement in the technological sectors, demand for skilled workers and average wages increase, making economic complexity a primary issue [36]. Furthermore, jobs created in urban areas are generally technology intensive. They require more exceptional technical training and a network of people sharing their knowledge. Therefore, the geographical location of individuals influences their abilities and reflects the influence of economic complexity on human development [8].

Greater economic complexity generates higher standards of living, leading to better education, healthcare, and social, water, and electrical services. Through the improvement of the varieties of goods available, the impact of economic complexity on income is direct [37]. By improving its economic complexity, a country can produce medicines, health equipment, and expand medical training, which in return, enhances the well-being of its citizens. In the unlikely case that economic complexity has no effects on income, it is anticipated that the exposure of individuals to new products will encourage human development.

Economic complexity means a country has more choices, more ideas and possible lifestyles, more capabilities, and is better able to adapt to people's needs [20]. The productive structure of a 
country positively influences economic agents' freedom of social choice [23]. We can easily believe that a country that has a high level of economic complexity is going to have more freedom of choice, thus impacting people's capacities and their sustainable development.

In more complex economies, individuals live longer, healthier lives with better education and better infrastructure [8]. Different studies have separated countries to see the effects of economic complexity on human development. Even though Latin American countries could not reach a high level of economic complexity, they still enjoyed high commodity prices, improving their social indicators [38]. However, the lack of economic diversification showed their lack of improvement in job quality. Furthermore, Latin American countries may not need improvement of their capacities because they are conditioned by commodity exports and social policies [8]. In contrast, to make their economies strong and diversified, Asian countries invested in human capital and technological innovation [39]. Japan was the first-ranked country in economic complexity in 2017. Public policies supported Asian countries throughout their development process [8]. Thus, we understand that depending on the countries being studied, the effects of ECI and HDI may be different [38]. In this paper, we decided to focus on developing countries.

\subsubsection{Counterarguments: The Non-Effect of Economic Complexity on Human Development}

Is there a causal relationship between economic complexity and human development? According to Lapatinas [2], economies with more diversified productive structures tend to be more socially developed. However, there is no proof of causality (the lagging of the economic complexity index was statistically insignificant).

"The more choice people have, the more freedom they have, and the more freedom they have, the more welfare they have" is not always accurate [40]. It counteracts the idea that economic complexity positively influences individuals' freedom of social choice [23]. The paradox of choice theory explains that having many possibilities of choice can be beneficial or detrimental to us. When the availability of choice is more prominent, we experience power, joy, autonomy, and control over our options. "Choice is what enables us to tell the world who we are and what we care about" [40]. However, if there are too many choices, we can feel overloaded, creating negative feelings and burdens regarding those choices. Individuals may also be unsatisfied due to the ecological unsustainability, which is the increasing demand for products that leads to more consumption, production, and resource exploitation. Thus, we could say that an increase in ECI does not mean a better HDI, which may also be explained by the fact that economic complexity is not a basic human need just like shelter, access to food, water, education, and health are. Therefore, it is not a core explanatory variable of social development [2]. Finally, it is essential to take the notion of time into consideration. With time, the diversification of the products and the economic situation of a country may change. The behaviors and perceptions of individuals may also change. All of these will impact the interrelation and direction of effects. Thus, we assume that over time, and subject to the different types of economic diversification, economic institutional changes (such as political stability and voice accountability), and the level of a country's economic complexity, the effects of ECI on HDI may change [2].

\subsection{The Effects of Income Inequality on Human Development}

Barack Obama stated that "income inequality is the defining challenge of our time." Poverty and income inequality influence health. The United Nations said that "children born into poverty are twice as likely to die before the age of five as those from wealthier families." Although income inequality decreased, and developing countries improved their conditions to favor exports and duty-free treatments, significant disparities in inequality still exist when it comes to access to health and education. Pope Francis said that we should be against the economy of exclusion.

In life, education and working hard are essential. Networks and belonging to a wealthy family are also relevant factors of social mobility and income distribution among individuals. The drivers 
and consequences of income inequalities are some of the most debated issues by policymakers and researchers nowadays [41].

Income is the household disposable income in a particular year It is accredited to each member, with an alignment to reflect variations in needs for households of different sizes (OECD). Wages, salaries, interest on a savings account, public transfer, dividends from shares of stock, rent, and profit all represent income. Income inequality is the unequal distribution of income among a population (inequality.org). Different databases propose Gini Index as a measurement of income inequality, such as the World Income Inequality Database (WIID) and the Organization for Economic Cooperation and Development OECD. Due to data availability, we decided to choose the GINI EHII from the University of Texas Inequality Project.

Regardless of culture, religion, and ideology, people care about inequality. Most of the time, inequality is a sign of a lack of income mobility and opportunity. Due to income inequality, a small part of the population holds power and human resources are not used at their optimal level, leading to economic instability and the risk of a crisis [41]. In addition, economies that experience a high level of income inequality are usually inclined to have lower levels of social mobility [42]. Income inequality levels are different depending on the country. Since 1990, emerging markets and developing countries EMDCs have experienced significant disparities: Asia and Eastern Europe have faced increases, while Latin America has seen some decline. In advanced economies, redistribution has alleviated market income inequality [41].

Inequality is divided between outcomes and opportunities. Differences in outcomes are measured by income, wealth, and expenditure. Inequality of opportunities is difficult to measure due to its conditions being beyond a person's control, such as gender and family background. We cannot separate outcomes from opportunities [41]. Thus, the distribution of opportunities and outcomes is essential for comprehending the nature and amplitude of income inequality. Social costs arise when there are high disparities of opportunities. A high variation of income weakens an individual's educational and occupational choices. Moreover, an inequality of outcomes leads to resource misallocation, corruption, and loss of confidence in institutions, worsening social cohesion and confidence in the future, and even leading to a financial crisis [43].

Access to health, education, and financial services are influenced by inequality of opportunity. In developed economies, health outcomes are similar across income groups. However, there are considerable differences in developing countries, where infant and female mortality rates are higher in poorer households [3,4]. In developed economies, inequality of education, on average, is not influenced by income inequality. For developing countries, as income inequality decreases, better access to education for lower-income households increases.

\subsection{The Effects of Economic Complexity on Income Inequality}

The belief that a country's productive structure can distribute income is not easy to prove. Previously used measures were simple qualitative approaches [5]. However, the Economic Complexity Index can utilize information regarding an economy's level of development and how countries generate and allocate income.

Economic complexity is a meaningful and negative predictor of income inequality $[5,44]$. The productive structure of a country is constituted by a broad mix of complex products, a vast scope of occupational choices, a flatter hierarchy of occupational structure, dispersed skills and knowledge, and extended class consciousness; all of these decrease income inequality [6]. Economic complexity, which is made up of a variety of complex products, lowers income inequality, similar to the Kuznets-Lewis wave, which affirms that structural changes explain changes in income distribution. Over time, economies with a high level of complexity experience a decrease in their level of income inequality [5].

Constantine and Khemraj [6] demonstrated this idea. Let us visualize a country having mainly low-value-added products, i.e., a low-complexity economy. In the beginning, countries receive high 
returns from economic activities. However, in this type of economy, the productive structure and employment depend mainly on low skills, which have low returns, and is one of the main factors influencing income disparities. Furthermore, low-value-added products are simple. They do not need high technologies, skills, or product knowledge, and are usually developed in small groups. The economic rewards of these products are taken by small groups of individuals, leading to disparities of income with the rest of the population. Low-value-added products do not need skilled labor, leading to limited choices of occupation in developing countries. The mass of unskilled workers will be regulated by a tall hierarchy within the professional structure, resulting in high inequalities, such as the growth of top incomes, low wages shares, and a small middle class.

However, this point of view can be criticized: the ECI could increase the GINI. During the 1980s, the US experienced a rise in wage inequality. It was mainly attributed to technological change, and in particular, skill-biased technical changes (SBTC) (Levy and Murnane and Katz and Murphy cited from [45-47]). The theory of skill-biased technical change comes from the idea that when a new technology rises, the demand for highly skilled workers increases too, leading to a rise in income inequality. Skill-biased technical change is "a shift in the production technology that favors skilled (e.g., more educated, more able, more experienced) labor over unskilled labor by increasing its relative productivity and, therefore, its relative demand" (p. 2) [48]. We could thus assume that when a country tries to become more complex, the focus will not be on natural resources or products that need low-skilled knowlege, but instead turns to products requiring higher skills, leading to the inequality of wages among individuals. This theory has been supported by many authors in the literature [47-49]. However, in the 1990s, income inequality stabilized even though countries like the US still experienced improvements in technology. According to Card and Dinardo [47], SBTC by themselves cannot explained the multiples changes in income inequality; some other factors, such as goods prices [50] or the real value of the minimum wage [47], are also some of the main causes of income inequality.

\subsection{Energy Consumption and Gender Inequality}

To achieve sustainable development, investments in technology and improvements in infrastructure and industries are important. By investing in diverse infrastructures, such as transport, irrigation, energy, information, and communication technology, a country has the opportunity to empower its communities. Manufacturing is one of the primary indicators of economic development and employment. Manufacturing can have both positive and negative impacts. On the positive side, industrialization has a job multiplication effect: "every job in manufacturing creates 2.2 jobs in other sectors" (United Nations). On the negative side, the manufacturing process creates enormous amounts of carbon dioxide emissions.

Environmental sustainability is a crucial concern among researchers and politicians, and different ways to analyze it has been explored [51,52] The seventh sustainable development goal is associated with energy, which is one of the main challenges in the world that we are facing nowadays. Access to electricity is fundamental to climate change, but also to jobs, incomes, security, and food production; it also interconnects with other sustainable development goals. As such, energy supports a vast range of activities. Nowadays, " 3 billion people rely on wood, coal, charcoal or animal waste for cooking and heating" (UNDP). The variations between modern energy consumption across countries characterize, to some degree, the vast differences in human development. How energy is created, distributed, and consumed influences the local, regional, and global environment, specifically in developing countries [7]. Energy poverty is highly present in developing countries, where firewood, dung, and charcoal are the principal energy resources consumed. All of this harms the environment and health of people due to the release of greenhouse gas emissions into the air [53,54].

Therefore, to decrease premature deaths, more effective technologies for clean fuel use during cleaning are needed. Furthermore, to create sustainable development and a better quality of life for everyone, we must improve access to energy and energy efficiency, and adopt renewable energy. 
Energy and gender are linked and impact human development in developing countries [7,9]. In those nations, food processing, water, and firewood collection is commonly a female-gendered role. Fuelwood has a harmful influence on women's health and their safety, such as in the form of back injuries due to heavy loads and hinders their ability to receive education.

Under the Millennium Development Goals, our societies have accomplished progress regarding gender equality and women's empowerment. The increased level of women's labor participation fundamentally changed our human society in terms of social, economic, and cultural development [55]. In life, men and women share many aspects of living in a complex and ubiquitous way. Although significant improvements have been made regarding gender inequality, women and girls still struggle with discrimination in their daily life, and the glass ceiling has not yet disappeared (UNDP). There are huge gaps when it comes to rewards and deprivations [56]. Although gender inequality is not an essential element of human rights, it is an important building block for peace, prosperity, and sustainability in our world.

Therefore, access to education, health care, proper jobs, and political life for women and girls can only improve sustainable development. Strengthening and protecting women's role in society is crucial because it improves health, increases levels of literacy and education, and controls population growth [55]. To achieve gender equality and reduce gender-based discrimination around the world, new legal frameworks, such as female equality in the workplace, need to be implemented (UNDP). Economies with a high level of human development frequently exhibit more gender parity than those economies with a low level of human development [57]. The gendered division of labor, such as through traditional gender roles, explains those disparities in developing countries. Another reason is the underinvestment in preventive health care [57]. Gender inequality hinders human development [9], but it only explains part of the problem. Gender equity should be improved to help individuals to reach their full potential and attain sustainable development. Unfortunately, this is not sufficient for improving well-being for the simple reason that men and women do not face the same opportunities in many aspects of life [57].

\section{Methodology}

\subsection{Variables and Data}

This study aimed to analyze the relationship between economic complexity, human development, and income inequality. We also included some cultural, political, and environmental variables, to provide a more comprehensive framework.

We first wanted to know whether the ECI impacted the HDI. Second, we analyzed whether income inequality (GINI) played a mediating role between our two main variables, and if so, whether it was a partial or full mediator. Finally, we examined the country-level effects of culture (gender inequality) and environment (energy consumption) on human development. We focused our research on developing countries.

To measure the dependent variable, we used the Human Development Index (HDI). Data are available for 189 countries from 1990 to 2017. The Economic Complexity Index (ECI) was used as a proxy to measure the productive structure of a nation. It is available on the Observatory of Economic Complexity (OEC) website [58]. The ECI is a tool that measures the knowledge intensity of the products exported by a country. Data are available for 129 countries from 1968 to 2017. For income inequality, we used the GINI EHII developed by the University of Texas Inequality Project. Data are available for 154 countries from 1964 to 2015. Then, we used two country-level predictors. The first one was gender inequality (GII), and the second one was energy consumption. We used fossil fuel consumption and renewable energy consumption as proxies. The variables came from the UNDP. Finally, the control variables were unemployment rate (UNEM), $\mathrm{CO}_{2}$ emissions, voice accountability (VA), and political stability and absence of violence (PS). The definitions of variables and useful information are provided in the Appendices A and B. 
This study relied on a panel of secondary data for 87 developing countries. The data period was between 1990 and 2017. In accordance with the hierarchical linear modeling methodology, the data was divided into two levels. Level 1 (year level) included yearly data (from 1990 to 2017) for all our countries for dependent, independent, and control variables, and the mediator. Level 2 (country level) contained proxies for the independent variable, control variables, the mediator, and the country-level predictors.

\subsection{Statistical Method}

As individual beings, we have the tendency to exist within organizational structures, such as families, business organizations, and countries. In business organizations, workers exist within a hierarchical structure that can include peer groups, production units, companies, sectors of the economy, geographic regions, and countries. A typical example to illustrate HLM is that students organized in classes vary even though they have teachers and courses in common [59].

Hierarchical linear modeling (HLM) is a statistical tool, developed to provide a better technique than fixed parameter simple linear regression for analyzing shared variances. HLM is used to analyze multilevel models and is similar to linear mixed models (LMM). By using HLM, we have the possibility to analyze the within-group versus the between-group effects, allowing us to decompose the covariance into different components. In other words, by using HLM, we can separate the covariance into components from the within-group effects (among different years within countries) and between-group effects (countries). In this research, we used HLM 8.00. When the independent variables are at different hierarchical levels, it is useful to use HLM to analyze the variance of the dependent variable.

HLM adopts a two-level approach. The base level is usually the individual level, which we call level 1 here. The analysis of level 1 is similar to that of an ordinary lest square (OLS) regression. At level 1, the within-group model is estimated independently of each group. At that level, an individual outcome variable is regressed into the individual-level predictors. In this study, that means that HDI was regressed into our control variables (unemployment, $\mathrm{CO}_{2}$ emissions, political stability, and voice accountability), independent variables (ECI), and mediator (GINI) individually. In this paper, the indicators of level 1 are the yearly data of each country for each parameter. Then, the level 1 parameter estimates are used as outcome variables in level 2, in which they are regressed into group-level variables (at the country level in our case). This was made possible because HLM allows us to analyze the hierarchical structure of the data, where observations are nested within groups. At level 2, we included GII and energy consumption as country-level predictors. We believe that culture and environmental sustainability take time to impact the HDI. That is why we decided to add them to level 2. Another reason is related to data availability for environmental sustainability: there are not enough yearly data from UNDP to include them in level 1 . At level 1, a minimum of 20 to 30 yearly data should be available for each country [60]; UNDP presents yearly data for fossil fuel consumption and renewable energy every five years from 1990 to 2010, and every year from 2010 to 2015.

In regression analysis, collinearity is a recurrent issue. In hierarchical linear models, it is even more important. Collinearity may appear between variables at the same level, but also between variables at two different levels (cross-level interaction). The best way to manage the multicollinearity issue in HLM is to center the independent variables of the model, especially the level-1 predictors. By centering the level-1 predictors around their respective group means, we can lower the correlations among the indicators used. The correlations between the second-level indicators and both the first-level variables and cross-level interactions are equal to zero when using centering around the group mean. Thus, the only possible source of problems will be from the correlations between cross-level interactions and level-1 variables. Centering around the group mean is also a way to independently analyze the effects of the level-1 and level-2 indicators in order to obtain more accurate estimates of the intercepts [59].

\section{Statistical Analysis}

In the mediation analysis, we first determined the relationship between the outcome variable (human development) and a predictor (economic complexity). The second step was to analyze whether 
that same predictor (ECI) could influence the mediator (income inequality). Once these two steps were successful, we could go to the last stage of the mediation, where both the predictor (ECI) and the mediator (GINI) were included in the same equation to predict the outcome variable (HDI). Stage 4 consisted of utilizing the predictors at level 2 .

\subsection{Step 1: Checking the Relationship between ECI and HDI}

In this stage, we analyzed whether economic complexity was a predictor of human development. To obtain robust results, we also ran the analysis with a 1-year lag for ECI and GINI, and another model at a 2-year lag for ECI and a 1-year for GINI.

\subsubsection{One-Way Analysis of Variance (ANOVA) with Random Effects: Null Model}

The first step in HLM is to determine whether significant differences regarding the outcome variable exist among the units of analysis at the group level. The null model, which is also named the "unconditional model" or "one-way ANOVA with random effects," is a model that predicts the level-1 intercept (mean) of the dependent variable as a random effect of the level-2 grouping variable, with no other predictors at level 1 or level 2 in the two-level model. We wanted to run the analysis of variance (ANOVA) to see whether there were significant differences between means, in other words, to confirm whether human development differed among countries. The null model is mathematically expressed in Equations (1) and (2):

$$
\begin{aligned}
\text { Level 1: } Y_{i j}=\beta_{0 j}+\varepsilon_{i j}, \\
\text { Level 2: } \beta_{0 j}=\gamma_{00}+u_{0 j} .
\end{aligned}
$$

In our models, $Y_{i j}$ represents human development in year i and country j. $\beta_{0 j}$ is the intercept or the average of country j's human development, $\gamma_{00}$ is the average country mean of human development for the population of countries, $u_{0 j}$ is the remaining unexplained random effect of $\beta_{0 j}$, and finally, the error term $\varepsilon_{\mathrm{ij}}$ is the unique effect associated with year $\mathrm{i}$ and country $\mathrm{j}$. To demonstrate whether there are significant differences among countries in human development, we used several indicators. As an OLS regression, the chi-square test was conducted. Then, we used the null model to calculate the intra-class correlation coefficient (ICC). ICC is a measure of the reliability of measurements or ratings:

$$
\text { ICC }=\tau_{00} /\left(\sigma^{2}+\tau_{00}\right) \quad \sigma^{2}+\tau_{00}=\text { Total variance }
$$

We also used the total deviation of each individual's score from the group mean, which is called the within-group variance, $\sigma^{2}$. The deviation of each group's mean from the overall mean was used, which is named the between-group variance, $\tau_{00}$. If the between-group variation is significantly greater than the within-group variation, it is likely that there is a statistically significant difference between groups. Finally, this model was also used as a baseline model for comparison with more complex models.

From Table 1 , for each sample size, $\mathrm{u}_{0 \mathrm{j}}$ was different from zero and the chi-square test for all models reached a significant level ( $p$-value $<0.001)$. At the same time, for the between-group variances, $\tau_{00}$ was significantly greater than the within-group variance. These results indicate that significant differences in human development between developing countries existed, where the results are robust with year lags, and further hierarchical linear modeling could be applied. The intra-class correlation (ICC) was $93 \%$. These high ratios demonstrate that the total variance of the outcome variable was explained by the between-group variance. Thus, these models reflected the robustness of the significant differences between developing countries in human development. The number of estimated parameters was two and deviances ranged from -2692.5743 to -2778.3405 . 
Table 1. Analysis of variance (ANOVA) with random effect for developing countries at year $t$ and with 1- and 2-year lags.

\begin{tabular}{cccc}
\hline Variable & Year t & 1-Year Lag & 2-Year Lag \\
\hline$\sigma^{2}$ & 0.00103 & 0.00104 & 0.00103 \\
$\mathrm{~T}$ & 0.01525 & 0.01452 & 0.01455 \\
$\mathrm{ICC}$ & $93.67 \%$ & $93.32 \%$ & $93.39 \%$ \\
\hline$\gamma_{00 \mathrm{HDI}}$ & $0.647332^{* * *}$ & $0.646800^{* * *}$ & $0.647011^{* * *}$ \\
\hline $\mathrm{u}_{0}$ & $7616.7295^{* * *}$ & $8053.2019^{* * *}$ & $8126.1811^{* * *}$ \\
\hline Deviance & -2692.5743 & -2778.3405 & -2777.7282 \\
\hline Parameters & 2 & 2 & 2 \\
\hline $\mathrm{n} 1$ & 741 & 765 & 763 \\
$\mathrm{n} 2$ & 59 & 61 & 61 \\
\hline
\end{tabular}

\subsubsection{One-Way ANCOVA with Random Effects}

The following sub-models were used to estimate the effects of different control variables on the outcome variable while controlling for the level- 2 context. Level 2 was assumed to have random effects. At this stage of the analysis, we did not have predictors at level 2. The purpose of this model was to check whether our control variables were highly correlated with the level of human development and to establish whether these control variables could explain the differences between countries in terms of human development. Each control variable should be inserted in the model one at a time. Due to a matter of space and to be clearer, we decided to show the results once all the control variables were included in the model. In the models, $\beta_{1 \mathrm{j}}$ to $\beta_{4 \mathrm{j}}$ represent the slope of each control variable, while $\gamma_{10}$ to $\gamma_{40}$ are the fixed slopes of $\beta_{1 \mathrm{j}}$ to $\beta_{4 \mathrm{j}}$. When we added a crucial variable in our model, part of the variance, either the variance of $\varepsilon_{\mathrm{ij}}$ at level 1 or the variance of $\mathrm{u}_{0 \mathrm{j}}$ at level 2 , should be explained by the newly inputted variable. In other words, the variance should decrease compared to the variance of the null model. It is important to know that if the value of the variance of $u_{0 j}$ at level 2 was significantly increasing, there was multicollinearity. Therefore, we used centering around the group mean, denoted as $\mathrm{CV}_{\mathrm{ij} \_}$centering, if needed. We followed the recommendation of Kreft and De Leeuw [61] to put the group mean, CV_mean, as a predictor back into level 2. The one-way ANCOVA with random effects around the group mean is mathematically expressed in Equations (4)-(9):

$$
\begin{gathered}
\text { Level 1: } \quad \mathrm{HDI}_{\mathrm{ij}}=\beta_{0 \mathrm{j}}+\beta_{1 \mathrm{j}} \times\left(\mathrm{CV}_{-} \mathrm{UNEM}_{\mathrm{ij} \text { c centering })+\beta_{2 \mathrm{j}} \times}\right. \\
\left(\mathrm{CV} \_\mathrm{CO} 2_{\mathrm{ij}_{-}} \text {centering }\right)+\beta_{3 \mathrm{j}} \times\left(\mathrm{CV}_{-} \mathrm{PV}_{\mathrm{ij} \_} \text {centering }\right)+\beta_{4 \mathrm{j}} \times\left(\mathrm{CV}_{-} \mathrm{VA}_{\mathrm{ij}}\right)+\mathrm{r}_{\mathrm{ij}}
\end{gathered}
$$

Level 2:

$$
\begin{aligned}
& \beta_{0 j}=\gamma_{00}+\gamma_{01} \times\left(C V_{-} \text {UNEM } \_ \text {mean }\right)+\gamma_{02} \times\left(C_{-}{ }_{-} C O 2_{j} \_ \text {mean }\right)+\gamma_{03} \times \\
& \left(\mathrm{CV}_{-} \mathrm{PV}_{\mathrm{j} \_} \text {mean }\right)+\mathrm{u}_{0 \mathrm{j}} \\
& \beta_{1 j}=\gamma_{10} \\
& \beta_{2 j}=\gamma_{20} \\
& \beta_{3 j}=\gamma_{30} \\
& \beta_{4 j}=\gamma_{40}
\end{aligned}
$$

By comparing the results from Table 2 with Table 1, the within-group variance $\sigma^{2}$ and between-group variance $\tau_{00}$ decreased, and deviances also reduced (less than $5.99\left(\chi^{2}(2), \alpha=0.05\right)$, under each control variable, except for VA. The results are robust between different year-lag models. This implies that the unemployment rate, $\mathrm{CO}_{2}$ emissions, and political stability played a significant role in explaining the differences in human development of developing countries. Although voice accountability was not a vital control variable, we kept it in and for further iterations of the model. 
Table 2. ANCOVA with random effects for developing countries with different year lags.

\begin{tabular}{|c|c|c|c|}
\hline Variable & Year $\mathbf{t}$ & 1-Year Lag & 2-Year Lag \\
\hline$\sigma^{2}$ & 0.00062 & 0.00061 & 0.0006 \\
\hline $\mathrm{T}$ & 0.0077 & 0.0073 & 0.00733 \\
\hline r1 & $48.89 \%$ & $49.16 \%$ & $49.10 \%$ \\
\hline r2 & $49.46 \%$ & $49.68 \%$ & $49.58 \%$ \\
\hline$\gamma_{00 \mathrm{HDI}}$ & 0.231554 * & 0.242742 * & $0.243996^{*}$ \\
\hline$\gamma_{01}$ UNEM Long & $0.054054^{* *}$ & 0.051763 ** & $0.051435^{* *}$ \\
\hline$\gamma_{02 \mathrm{CO}_{2} \text { Long }}$ & $0.032998^{* * *}$ & $0.032432 * * *$ & $0.032390^{* * *}$ \\
\hline$\gamma_{03}$ PV Long & $0.095421^{* * *}$ & $0.095191^{* * *}$ & $0.094731^{* * *}$ \\
\hline$\gamma_{10 \text { UNEM Short }}$ & 0.561 & 0.495 & 0.277 \\
\hline$\gamma_{20} \mathrm{CO}_{2}$ Short & $0.095469^{* * *}$ & $0.096436^{* * *}$ & $0.095586^{* * *}$ \\
\hline$\gamma_{30}$ PV Short & 0.523 & 0.446 & 0.372 \\
\hline$\gamma_{40}$ VA Short & 0.811 & 0.764 & 0.813 \\
\hline $\mathrm{u}_{0}$ & $7491.7361^{* * *}$ & $7772.8073^{* * *}$ & $7868.3600 * * *$ \\
\hline Deviance & -3029.30 & -3145.3787 & -3151.2439 \\
\hline Parameters & 9 & 9 & 9 \\
\hline
\end{tabular}

Regarding the fixed slopes, only $\gamma_{20}$ was significant: $\mathrm{CO}_{2}(p$-value $<0.001)$. The slopes of UNEM $\left(\gamma_{10}\right)$, PV $\left(\gamma_{30}\right)$, and VA $\left(\gamma_{40}\right)$ were insignificant. In other words, in the short term, only $\mathrm{CO}_{2}$ emissions influenced the human development of developing countries in a positive way. Regarding the slopes of averages, all the control variables were positively significant, with a $p$-value smaller than 0.01 for $\operatorname{UNEM}\left(\gamma_{01}\right)$, and a $p$-value smaller than 0.001 for $\mathrm{CO}_{2}\left(\gamma_{02}\right)$ and PV $\left(\gamma_{03}\right)$. VA did not appear because it was not centered around the group mean. The results were robust for each year lag tested. Therefore, in the long term, the unemployment rate, $\mathrm{CO}_{2}$ emissions, and political stability positively impacted human development in developing countries.

Once all the control variables were included in the model, the explanatory power reached around $49 \%$ at level 1 and 50\% at level 2 under different year lags. The results were high and similar, showing robustness.

\subsubsection{Random Coefficient Regression with the ECI as the Independent Variable}

In the sub-models of Table 3, the independent variable, the Economic Complexity Index, was included into each model to determine whether it could help to explain differences between countries at the level of human development. To prevent multi-collinearity, we used centering around the group mean and put the group mean back in as a predictor in level $2 . \beta_{5 j}$ is the slope of the ECI, $\gamma_{50}$ is the fixed slope of $\beta_{5 j}$, and $\gamma_{05}$ is the slope of the mean of ECI. The model is expressed as in the following Equations (10)-(16):

Level 1: $\quad \mathrm{HDI}_{\mathrm{ij}}=\beta_{0 \mathrm{j}}+\beta_{1 \mathrm{j}} \times\left(\mathrm{UNEM}_{\mathrm{ij}}\right.$ centering $)+\beta_{2 \mathrm{j}} \times\left(\mathrm{CO} 2_{\mathrm{ij} \_}\right.$centering $)+\beta_{3 \mathrm{j}} \times$ $\left(C V_{-} P_{\mathrm{ij} \_}\right.$centering $)+\beta_{4 \mathrm{j}} \times\left(\mathrm{CV}_{-} \mathrm{VA}_{\mathrm{ij}}\right)+\beta_{5 \mathrm{j}} \times\left(\mathrm{ECI}_{\mathrm{ij} \_ \text {centering }}\right)+\mathrm{r}_{\mathrm{ij}}$

Level 2: $\quad \beta_{0 \mathrm{j}}=\gamma_{00}+\gamma_{01} \times\left(\mathrm{UNEM}_{\mathrm{j} \_}\right.$mean $)+\gamma_{02} \times\left(\mathrm{CO}_{\mathrm{j} \_}\right.$mean $)+\gamma_{03} \times$

$$
\left(\mathrm{CV}_{-} \mathrm{PV}_{\mathrm{j} \_} \text {mean }\right)+\gamma 05 \times\left(\mathrm{ECI}_{\mathrm{j}_{-}} \text {mean }\right)+\mathrm{u}_{0 \mathrm{j}}
$$

$$
\begin{aligned}
& \beta_{1 j}=\gamma_{10} \\
& \beta_{2 j}=\gamma_{20} \\
& \beta_{3 j}=\gamma_{30} \\
& \beta_{4 j}=\gamma_{40}
\end{aligned}
$$




$$
\beta_{5 j}=\gamma_{10}+u_{5 j}
$$

By comparing the results of Table 3 with Table 2, the within-group variance $\sigma^{2}$, between-group variance $\tau_{00}$, and deviances decreased. The results were robust between different year lag models. This implies that the ECI played a significant role in explaining the differences in the human development of developing countries. The fixed slope $\gamma_{50}$ was slightly positively significant $(p$-value $<0.05)$. The slope of average $\gamma_{05}$ was strongly and positively significant ( $p$-value $<0.001$ ). Therefore, the ECI positively influenced human development in developing countries in both the short and long term. The explanatory power reached $56 \%$ at level 1 under different year lags, and 56\% at level 2. Criticism could be made regarding the slight improvements (around 7\%) of explanatory power over the previous model (one-way ANCOVA). However, that number does not represent the explanatory power of the ECI. We also ran a model with no control variables to see what the explanatory power of the ECI could be, and we reached around $45 \%$ at both levels, showing the strong effect of the ECI on the HDI.

Table 3. Coefficient regression with the Economic Complexity Index (ECI) as a predictor of the Human Development Index (HDI) for developing countries using different year lags.

\begin{tabular}{|c|c|c|c|}
\hline Variable & Year $t$ & 1-Year Lag & 2-Year Lag \\
\hline$\sigma^{2}$ & 0.00033 & 0.00035 & 0.00032 \\
\hline$\tau$ & 0.0069 & 0.00651 & 0.00647 \\
\hline r1 & $55.59 \%$ & $55.91 \%$ & $56.42 \%$ \\
\hline r2 & $54.82 \%$ & $55.23 \%$ & $55.61 \%$ \\
\hline$\gamma_{00 \mathrm{HDI}}$ & $0.433226^{* * *}$ & $0.430384^{* * *}$ & $0.417257^{* * *}$ \\
\hline$\gamma_{01}$ UNEM Long & $0.037774+$ & 0.039390 * & 0.040626 * \\
\hline$\gamma_{02} \mathrm{CO}_{2}$ Long & $0.017262+$ & 0.017446 * & 0.018443 * \\
\hline$\gamma_{03}$ PV Long & $0.060067^{* *}$ & $0.058922 * *$ & $0.059574^{* *}$ \\
\hline$\gamma_{05 \mathrm{ECI} \text { Long }}$ & $0.080015^{* * *}$ & $0.082332^{* * *}$ & $0.082362^{* * *}$ \\
\hline$\gamma_{10}$ UNEM Short & -0.010936 * & -0.011973 * & $-0.014211 *$ \\
\hline$\gamma_{20} \mathrm{CO}_{2}$ Short & $0.086817^{* * *}$ & $0.087993^{* * *}$ & $0.091384^{* * *}$ \\
\hline$\gamma_{30 \text { PV Short }}$ & 0.842 & 0.992 & 0.984 \\
\hline$\gamma_{40}$ VA Short & 0.607 & 0.801 & 0.985 \\
\hline$\gamma_{50 \text { ECI Short }}$ & $0.035246^{*}$ & $0.044384^{* *}$ & $0.047224 * *$ \\
\hline $\mathrm{u}_{0}$ & $12061.0576^{* * *}$ & $12090.7101^{* * *}$ & $12848.6747^{* * *}$ \\
\hline $\mathrm{u}_{5}$ & $710.2992 * * *$ & $632.7076^{* * *}$ & $612.0810^{* * *}$ \\
\hline Deviance & -3343.1988 & -3442.7314 & -3471.8529 \\
\hline Parameters & 11 & 11 & 11 \\
\hline
\end{tabular}

\subsubsection{Summary of Step 1}

At this stage of the analysis, we checked whether the ECI was a predictor of the HDI. We found that while controlling for the unemployment rate, $\mathrm{CO}_{2}$ emissions, political stability, and voice accountability, ECI had significant positive short- and long-term effects on the HDI in developing countries. Therefore, we could run the second step of the analysis and analyze whether the ECI was a predictor of GINI, and in step 3, examine whether there was mediation.

\subsection{Step 2: Checking the Relationship between the ECI and GINI}

In this step, we analyzed whether economic complexity was a predictor of income inequality. Just as in step 1, we had to run a null model to see whether significant differences in income inequality existed between the units of analysis at the group level. Once we confirmed that such differences between developing countries existed, we then ran a random coefficient regression model to analyze the relationship between the ECI and GINI. 


\subsubsection{Null Model with GINI as the Outcome Variable}

From Table 4 , for each sample size, $\mathrm{u}_{0 \mathrm{j}}$ was different from zero and the chi-square test for all models reached a significant level $(p$-value $<0.001)$. At the same time, the between-group variance $\tau_{00}$ was significantly greater than the within-group variance $\sigma^{2}$. These results indicate that significant differences between developing countries existed in terms of income inequality, that results were robust with year lags, and further hierarchical linear modeling could be applied. The intra-class correlation (ICC) was around $82 \%$. These high ratios demonstrated that the total variance of the outcome variable was explained by the between-group variance. The number of estimated parameters was two and the deviances ranged from -2328.31 to -2387.96 .

Table 4. ANOVA with random effects for developing countries with GINI as the outcome variable.

\begin{tabular}{cccc}
\hline Variable & Year $\mathbf{t}$ & 1-Year Lag & 2-Year Lag \\
\hline$\sigma^{2}$ & 0.00184 & 0.00189 & 0.00189 \\
$\mathrm{~T}$ & 0.00855 & 0.00851 & 0.00851 \\
$\mathrm{ICC}$ & $82.29 \%$ & $81.83 \%$ & $81.83 \%$ \\
\hline$\gamma_{00 \mathrm{GINI}}$ & $3.857052^{* * *}$ & $3.856002^{* * *}$ & $3.855823^{* * *}$ \\
\hline $\mathrm{u}_{0}$ & $3754.1971^{* * *}$ & $3757.2620^{* * *}$ & $3749.6578^{* * *}$ \\
\hline Deviance & -2328.314 & -2387.9649 & -2380.6901 \\
Parameters & 2 & 2 & 2 \\
\hline \multicolumn{4}{c}{ Note: } \\
\end{tabular}

\subsubsection{Random Coefficient Regression with ECI as a Predictor of GINI}

In comparison with the previous models Table 4 (with GINI as the outcome), the within-group variance $\sigma^{2}$ and between-group variance $\tau_{00}$ of Table 5 decreased; the deviances also decreased (less than $5.99\left(\chi^{2}(2), \alpha=0.05\right)$. The results were robust between different year lag models. This implies that the ECI played a significant role in explaining the differences in income inequality of developing countries. The fixed slope $\gamma_{10}$ was insignificant. The slope of the average $\gamma_{01}$ was strongly and negatively significant $(p$-value $<0.001)$. Therefore, the ECI did not influence income inequality in the short term, but significantly reduced income inequality in the long run in developing countries. The explanatory power reached $42-46 \%$ at level 1 , and $46-50 \%$ at level 2 .

Table 5. Coefficient regression with the ECI as a predictor of GINI.

\begin{tabular}{cccc}
\hline Variable & Year t & 1-Year Lag & 2-Year Lag \\
\hline$\sigma^{2}$ & 0.00136 & 0.00149 & 0.00143 \\
$\mathrm{~T}$ & 0.00424 & 0.00451 & 0.00455 \\
\hline $\mathrm{r} 1$ & $46.10 \%$ & $42.31 \%$ & $42.50 \%$ \\
$\mathrm{r} 2$ & $50.00 \%$ & $46.55 \%$ & $46.15 \%$ \\
\hline$\gamma_{00 \mathrm{GINI}}$ & $3.833857^{* * *}$ & $3.831476^{* * *}$ & $3.831742^{* * *}$ \\
$\gamma_{01 \mathrm{ECI}}$ & $-0.112376^{* * *}$ & $-0.107986^{* * *}$ & $-0.107903^{* * *}$ \\
$\gamma_{10 \mathrm{ECI}}$ & $0.558^{* * *}$ & $0.883^{* * *}$ & 0.526 \\
\hline $\mathrm{u}_{0}$ & $2622.4022^{* * *}$ & $2414.7848^{* * *}$ & $2552.1679^{* * * *}$ \\
$\mathrm{u}_{1}$ & $281.1470^{* * *}$ & $231.4309^{* * *}$ & $285.4965^{* * *}$ \\
\hline Deviance & -2499.4014 & -2516.9643 & -2531.2275 \\
Parameters & 4 & 4 & 4 \\
\hline \multicolumn{4}{c}{ Note: ${ }^{* * *}: p$-value $<0.001}$. \\
\end{tabular}




\subsubsection{Summary of Step 2}

We found that developing economies saw their level of income inequality decrease in the long term when they experienced a higher level of economic complexity. In the short term, developing countries did not experience any effects from the ECI on GINI.

\subsection{Step 3: Mediation Analysis}

The following models were compared with those from Table 3. Once GINI was included in the equation, the relationship between ECI and HDI was analyzed. $\beta_{6 j}$ represents the slope of GINI. $\gamma_{60}$ is the fixed slope of $\beta_{6 j}$. $\gamma_{06}$ is the slope of the mean of GINI. The model equation was as given in Equations (17)-(24):

Level 1:

$$
\begin{aligned}
& \mathrm{HDI}_{\mathrm{ij}}=\beta_{0 \mathrm{j}}+\beta_{1 \mathrm{j}} \times\left(\mathrm{UNEM}_{\mathrm{ij} \_} \text {centering }\right)+\beta_{2 \mathrm{j}} \times\left(\mathrm{CO}_{\mathrm{ij} \_} \text {centering }\right)+\beta_{3 \mathrm{j}} \times
\end{aligned}
$$

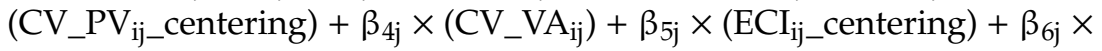

$$
\begin{aligned}
& \left(\mathrm{GINI}_{\mathrm{ij} \_} \text {centering }\right)+\mathrm{r}_{\mathrm{ij}} \\
& \text { Level 2: } \quad \beta_{0 j}=\gamma_{00}+\gamma_{01} \times\left(\mathrm{UNEM}_{\mathrm{j} \_} \text {mean }\right)+\gamma_{02} \times\left(\mathrm{CO} 2_{\mathrm{j} \_} \text {mean }\right)+\gamma_{03} \times \\
& \left(\mathrm{CV} \_ \text {PV } V_{j \_} \text {mean }\right)+\gamma_{05} \times\left(\mathrm{ECI}_{\mathrm{j} \_} \text {mean }\right)+\gamma_{06} \times\left(\mathrm{GINI}_{\mathrm{j} \_} \text {mean }\right)+\mathrm{u}_{0 \mathrm{j}} \\
& \beta_{1 j}=\gamma_{10} \\
& \beta_{2 j}=\gamma_{20} \\
& \beta_{3 j}=\gamma_{30} \\
& \beta_{4 j}=\gamma_{40} \\
& \beta_{5 j}=\gamma_{50}+u_{5 j} \\
& \beta_{6 j}=\gamma_{60}+u_{6 j}
\end{aligned}
$$

The results of Table 6 are compared with the results of Table 3. The within-group variance $\sigma^{2}$ decreased for all models but slightly increased for the between-group variance $\tau_{00}$. The deviance was significantly reduced for the three models. We can, therefore, infer that GINI was somehow a good predictor of the HDI in the short term but not in the long term. The fixed slope of GINI $\gamma_{60}$ is slightly significant at year $\mathrm{t}(p$-value $<0.1)$ and at lag year $1(p$-value $<0.05)$, but it was insignificant at lag year 2. Furthermore, the slope of the average $\gamma_{06}$ was not significant.

However, the main purpose of this table was to establish the effects of the ECI on the HDI. If the impact of the ECI on the HDI disappeared, we could conclude that GINI played a role as a full mediator, but if those effects were only reduced, then GINI was only a partial mediator. As we can see from $\gamma_{05}$ and $\gamma_{50}$, the ECI still had positive long-term effects ( $p$-value $\left.<0.001\right)$ and short-term effects $(p$-value $<0.01$ ) on the HDI. However, this was not enough to determine whether GINI was a full or partial mediator. Thus, we analyzed the $\mathrm{t}$-ratios. Under the year $\mathrm{t}$ model, the $\mathrm{t}$-ratio of the ECI decreased from 3.602 to 3.014 in the long term, and from 2.253 to 2.016 in the short term. In the model using the ECI and GINI at one year of lag, the t-ratio decreased from 3.867 to 3.814 in the long run and from 3.083 to 2.906 in the short term. We concluded that the effects of the ECI on the HDI decreased when GINI was included. Therefore, GINI played a role as a partial mediator between the ECI and the HDI. In the last model, we included ECI with two years of lag and GINI with one year of lag. In that model, the t-ratio decreased in the short term but increased from 3.8 to 3.958 in the long term. Therefore, if the ECI became relevant earlier in time, GINI did not play a role as a mediator anymore. 
Table 6. The ECI and GINI as predictors of the HDI for developing countries.

\begin{tabular}{|c|c|c|c|}
\hline Variable & Year $\mathbf{t}$ & 1-Year Lag & 2-Year Lag \\
\hline$\sigma^{2}$ & 0.00026 & 0.00026 & 0.00024 \\
\hline$\tau$ & 0.00704 & 0.00661 & 0.00658 \\
\hline r1 & $55.16 \%$ & $55.85 \%$ & $56.23 \%$ \\
\hline r2 & $53.95 \%$ & $54.59 \%$ & $54.90 \%$ \\
\hline$\gamma_{00 \mathrm{HDI}}$ & 0.384 & 0.154 & 0.237 \\
\hline$\gamma_{01}$ UNEM Long & 0.038103 * & $0.037949 *$ & 0.039259 * \\
\hline$\gamma_{02} \mathrm{CO}_{2}$ Long & $0.017392+$ & $0.016204+$ & $0.016963+$ \\
\hline$\gamma_{03}$ PV Long & $0.059760 * *$ & $0.059194 * *$ & $0.058472 * *$ \\
\hline$\gamma_{05 \text { ECI Long }}$ & $0.075910 * *$ & $0.079251^{* * *}$ & $0.082781^{* * *}$ \\
\hline$\gamma_{06 \text { GINI Long }}$ & 0.833 & 0.516 & 0.681 \\
\hline$\gamma_{10}$ UNEM Short & $-0.012121 *$ & $-0.013069 *$ & -0.015208 * \\
\hline$\gamma_{20} \mathrm{CO}_{2}$ Short & $0.084765^{* * *}$ & $0.083236^{* * *}$ & $0.084760 * * *$ \\
\hline$\gamma_{30}$ PV Short & 0.608 & 0.915 & 0.939 \\
\hline$\gamma_{40}$ VA Short & 0.662 & 0.934 & 0.778 \\
\hline$\gamma_{50}$ ECI Short & 0.029855 * & $0.038449 * *$ & $0.042275^{* *}$ \\
\hline$\gamma_{60 \text { GINI Short }}$ & $0.086942+$ & 0.089985 * & 0.162 \\
\hline $\mathrm{u}_{0}$ & $15,222.0698^{* * *}$ & $15,755.6869^{* * *}$ & $17,096.9108^{* * *}$ \\
\hline $\mathrm{u}_{5}$ & $686.5213^{* * *}$ & $692.0437^{* * *}$ & $669.0069 * * *$ \\
\hline $\mathrm{u}_{6}$ & $249.6758^{* * *}$ & $276.3753^{* * * *}$ & $285.3140^{* * *}$ \\
\hline Deviance & -3419.363 & -3550.9787 & -3593.6288 \\
\hline Parameters & 13 & 13 & 13 \\
\hline
\end{tabular}

\subsection{Step 4: Full Model-Predictors at Level 2}

The full model, also called the intercepts-and-slopes-as-outcomes model, was built by adding each country predictor into level-2. Each predictor was added without centering. We included gender inequality (GII), fossil fuel (FF), and renewable energy (RE). $\gamma_{07}$ represents the slope of the predictor $\mathrm{RE}, \gamma_{08}$ represents the slope of the predictor $\mathrm{FF}$, and $\gamma_{09}$ represents the slope of the predictor GII. The model equation was as given in Equations (25)-(32):

Level 1: $\quad \mathrm{HDI}_{\mathrm{ij}}=\beta_{0 \mathrm{j}}+\beta_{1 \mathrm{j}} \times\left(\mathrm{UNEM}_{\mathrm{ij} \_}\right.$centering $)+\beta_{2 \mathrm{j}} \times\left(\mathrm{CO} 2_{\mathrm{ij} \_}\right.$centering $)+\beta_{3 \mathrm{j}} \times$ $\left(\mathrm{CV}_{-} \mathrm{PV}_{\mathrm{ij} \_}\right.$centering $)+\beta_{4 \mathrm{j}} \times\left(\mathrm{CV}_{-} \mathrm{VA}_{\mathrm{ij}}\right)+\beta_{5 \mathrm{j}} \times\left(\mathrm{ECI}_{\mathrm{ij}-}\right.$ Centering $)+\beta_{6 \mathrm{j}} \times$

$$
\left(\mathrm{GINI}_{\mathrm{ij} \_} \text {centering }\right)+\mathrm{r}_{\mathrm{ij}}
$$

Level 2: $\quad \beta_{0 \mathrm{j}}=\gamma_{00}+\gamma_{01} \times\left(\mathrm{UNEM}_{\mathrm{j} \_}\right.$mean $)+\gamma_{02} \times\left(\mathrm{CO}_{\mathrm{j} \_}\right.$mean $)+\gamma_{03} \times$

$\left(C V_{-} V_{\text {j_- mean }}\right)+\gamma_{04} \times\left(\mathrm{CV}_{-} \mathrm{VA}_{\mathrm{j}}\right)+\gamma_{05} \times\left(\mathrm{ECI}_{\mathrm{j}_{-}}\right.$mean $)+\gamma_{06} \times\left(\mathrm{GINI}_{\mathrm{j} \_}\right.$mean $)+\gamma_{07} \times$

$$
\begin{gathered}
\left(\mathrm{RE}_{\mathrm{j}}\right)+\gamma_{08} \times\left(\mathrm{FF}_{\mathrm{j}}\right)+\gamma_{09} \times\left(\mathrm{GII}_{\mathrm{j}}\right)+\mathrm{u}_{0 \mathrm{j}} \\
\beta_{1 \mathrm{j}}=\gamma_{10} \\
\beta_{2 \mathrm{j}}=\gamma_{20} \\
\beta_{3 \mathrm{j}}=\gamma_{30} \\
\beta_{4 j}=\gamma_{40} \\
\beta_{5 \mathrm{j}}=\gamma_{50}+\mathrm{u}_{5 \mathrm{j}} \\
\beta_{6 j}=\gamma_{60}+\mathrm{u}_{6 j}
\end{gathered}
$$

Compared to Table 6 , in these models, Table 7, the within-group variance $\sigma^{2}$ did not decrease for the simple reason that we did not include any predictors at level 1 but rather only at level 2 . The between-group variance $\tau_{00}$ and deviances significantly decreased for the three models. We can, 
therefore, infer that GII, fossil fuel, and renewable energy were good country-level predictors of HDI. The average slope of renewable energy $\gamma_{07}$ was negatively significant to the HDI. The same was true for the slope of gender inequality $\gamma_{09}$, while the average slope of fossil fuel $\gamma_{08}$ was positively significant. The explanatory power reached a high level under each model, at around $77 \%$ at both level 1 and level 2.

Table 7. Full models for developing countries.

\begin{tabular}{|c|c|c|c|}
\hline Variable & Year $\mathbf{t}$ & 1-Year Lag & 2-Year Lag \\
\hline$\sigma^{2}$ & 0.00026 & 0.00026 & 0.00024 \\
\hline $\mathrm{T}$ & 0.00335 & 0.00337 & 0.00335 \\
\hline r1 & $77.83 \%$ & $76.67 \%$ & $76.96 \%$ \\
\hline r2 & $78.02 \%$ & $76.78 \%$ & $76.97 \%$ \\
\hline$\gamma_{00 \mathrm{HDI}}$ & 0.812571 * & $0.671297+$ & 0.148 \\
\hline$\gamma_{01}$ UNEM Long & $0.019983+$ & $0.021046+$ & 0.022412 * \\
\hline$\gamma_{02} \mathrm{CO}_{2}$ Long & 0.560 & 0.665 & 0.843 \\
\hline$\gamma_{03}$ PV Long & 0.843 & 0.691 & 0.636 \\
\hline$\gamma_{05}$ ECI Long & 0.041231 * & $0.052342 * *$ & 0.051051 * \\
\hline$\gamma_{06 \text { GINI Long }}$ & 0.585 & 0.917 & 0.772 \\
\hline$\gamma_{07 \text { Renew.Energy }}$ & $-0.015839^{* *}$ & -0.013500 * & $-0.012913 *$ \\
\hline$\gamma_{08}$ Fossil Fuel & $0.062586^{* *}$ & 0.055164 * & $0.055634^{* *}$ \\
\hline$\gamma_{09 \mathrm{GII}}$ & $-0.393715^{* * *}$ & $-0.406174^{* * *}$ & $-0.406640^{* * *}$ \\
\hline$\gamma_{10 \text { UNEM Short }}$ & -0.012286 * & $-0.013168 *$ & -0.015204 * \\
\hline$\gamma_{20} \mathrm{CO}_{2}$ Short & $0.084666^{* * *}$ & $0.083209^{* * *}$ & $0.084816^{* * *}$ \\
\hline$\gamma_{30}$ PV Short & 0.653 & 0.953 & 0.984 \\
\hline$\gamma_{40}$ VA Short & 0.513 & 0.912 & 0.914 \\
\hline$\gamma_{50}$ ECI Short & $0.030176^{*}$ & $0.038724^{* *}$ & $0.042153 * *$ \\
\hline$\gamma_{60 \text { GINI Short }}$ & $0.085360+$ & $0.089601 *$ & 0.159 \\
\hline $\mathrm{u}_{0}$ & $7193.6561 * * *$ & $7867.6397 * * *$ & $8562.9382^{* * *}$ \\
\hline $\mathrm{u}_{5}$ & $692.1161^{* * *}$ & $697.2811^{* * *}$ & $671.0575^{* * *}$ \\
\hline $\mathrm{u}_{6}$ & $249.1473 * * *$ & $274.3604^{* * *}$ & 284.3652 *** \\
\hline Deviance & -3443.0884 & -3572.0911 & -3613.7736 \\
\hline Parameters & 16 & 16 & 16 \\
\hline
\end{tabular}

\subsection{Comments Regarding Developed Countries}

Sustainable development is not only decisive for developing countries, but also for developed economies. Thus, we ran the same model for developed countries. However, governance indicators, unemployment rate, and $\mathrm{CO}_{2}$ emissions were not significant control variables. Furthermore, the ECI was not a predictor of human development in developed countries, and even obtained some collinearity problems. GINI was slightly significant in the short term, and only gender inequality played a role as a significant predictor at level 2. We thus understand that predictors of sustainable development are different depending on the type of countries being studied.

\section{Discussion and Conclusions}

What is development? How can a country develop? Income, in particular GDP per capita, cannot be considered the only way to measure development. Nations must focus on the way their citizens live their lives and how to improve it. Therefore, human development, which focuses on income, education, and health factors, became of great importance in the study of the sustainable development of countries.

This article contributes to the field of research by integrating not only political factors to understand human development, but also economic, cultural, and environmental indicators. We were interested in a newly created indicator, namely the Economic Complexity Index, and whether its effect on human 
development could be mediated by income inequality, which was suggested by Ferraz et al. [8]. Furthermore, through our results, we found out that the same factors could not be used for both developing and developed countries; in this study, the focus was on developing countries, where the model that we presented was not significant for developed economies. Finally, we used hierarchical linear modeling (HLM) as our statistical tool. HLM allowed us to analyze more than 50 countries at a time, from 1990 to 2017, and evaluate the yearly and country effects of different predictors in the short and long term.

The results of our analysis proved the effects of economic complexity on human development, mediated by income inequality. The results were robust at year $t$, and for lags of one and two years. The variation of sustainable development in developing countries was explained by several control variables, which were the unemployment rate, $\mathrm{CO}_{2}$ emissions, and political stability (Table 2). The unemployment rate positively influenced human development. This view can be quite contradictory, but back in the 1960s and 1970s, this kind of behavior could be explained by different points of view. First, low-income individuals (the poor) cannot bear the cost of being unemployed. Second, in developing countries, labor markets are open and flexible enough to let individuals find work. Finally, if there is unemployment, it is a representation of individuals that can finance the cost of being unemployed while searching for jobs with higher earnings [62]. In some situations, unemployment and crisis may be beneficial to human development. In the case of high levels of unemployment, a government has to provide better social security and educational systems, but also a better legal framework to fight crime and corruption. Thus, this will become an urgent task and lead to better sustainable development [19].

$\mathrm{CO}_{2}$ emissions positively influence human development. To fulfill basic social needs, economic growth, and human development, individuals need to have access to energy services [7]. Therefore, even though $\mathrm{CO}_{2}$ emissions are directly detrimental to a person's health, it also means that manufacturing is improving, there are better infrastructures, agricultural productivity increases, and there are better electrical services. Access to energy, and especially fossil fuel, which creates $\mathrm{CO}_{2}$ emissions, is required to achieve growth and improve human development in developing countries $[7,63]$. It was estimated that $\mathrm{CO}_{2}$ emissions are needed for India to reach a greater HDI above 0.8 [64]. Finally, political stability also positively influences human development in the long run. If a country wants to obtain a competitive advantage in a specific industry, having a complex economy is not always enough. A nation should also possess a social system that improves cultural values and provides better governance [65]. We believe that it is the same when it comes to sustainable development. Global governance is the key to reaching a higher level of human development for everyone [66].

Then, we examined the relationship between the ECI and the HDI, which was the primary purpose of this paper. The ECI had short- and long-term positive effects on the HDI in developing countries, which was robust with different year lags (Table 3). The results are supported by our literature review. Greater economic complexity generates higher standards of living, leading to better education, healthcare, and social, water, and electrical services. Through the increase of the varieties of goods available, the impact of economic complexity on income is direct [37]. By improving its economic complexity, a country can produce medicines, health equipment, and expand medical training, which in return, enhances the well-being of its citizens. Furthermore, economic complexity means there are more choices, more ideas and possible lifestyles, more capabilities, and a better adaptation to people's needs [20]. In more complex economies, individuals live longer and healthier, and have better education and infrastructures [8].

The overall environment of human development is complex, and economic complexity may not have a direct impact on sustainable development. Therefore, we included GINI as a mediator. Among different developing economies, the ECI had negative long-term effects on GINI (Table 5). In other words, if developing countries became more complex in their productive capabilities, they saw a reduction in income inequalities $[5,6]$. We also found that among developing countries, the positive 
effects of economic complexity on human development were reduced because of income inequalities (Table 6). Developing economies can experience a better quality of health and education if they improve their productive structure. However, if they have a high level of income inequalities, these positive effects will decrease. We may explain this behavior through the fact that some individuals in those countries, namely those with less income, may not have access to education, and therefore cannot get the knowledge needed to create new and better products that can improve their quality of life.

Finally, country-level predictors were included in the model. Fossil fuel consumption positively influenced human development in developing countries. Access to health, education, information, agriculture, and services is not possible without energy. In developing countries, the primary source of energy comes from fossil fuels and is required to achieve growth and improve human development $[7,67]$. Renewable energy, which negatively affected human development in our research, is more expensive and thus more challenging to obtain in those countries. Finally, gender inequality also negatively influenced human development. Access to education, health care, proper jobs, and political positions for women and girls can only improve sustainable development. Strengthening and protecting women's roles in society is crucial because it improves health and increases levels of literacy and education, as well as controls population growth [55]. Economies with a high level of human development frequently exhibit more gender parity than those economies with a low level of human development [57].

Through our results, we found that the same factors could not be used for both developing and developed countries. Therefore, in future research, a new comprehensive model, focusing on sustainable development in developed countries should be created. New indicators, such as immigration, could be included.

Author Contributions: Conceptualization, E.L.C. and F.H.; formal analysis, E.L.C.; methodology, E.L.C. and F.H.; supervision, F.H.; Writing-original draft, E.L.C.; writing-review and editing, E.L.C. All authors have read and agreed to the published version of the manuscript.

Funding: This research received no external funding.

Acknowledgments: We would like to express our thanks and gratitude to Yunlin University for their acceptance and useful comments at the 2019 International Conference on Design with Intelligence and Humanity (ICDIH), and to Southern Taiwan University of Science and Technology for their interest and comments at the 15th International Conference on Knowledge-Based Economy and Global Management.

Conflicts of Interest: The authors declare no conflict of interest.

\section{Appendix A. List of Countries}

$\begin{array}{lll}\text { Albania } & \text { Jordan } & \text { Tanzania } \\ \text { Algeria } & \text { Kazakhstan } & \text { Thailand } \\ \text { Angola } & \text { Kenya } & \text { Togo } \\ \text { Argentina } & \text { Kuwait } & \text { Trinidad and Tobago } \\ \text { Azerbaijan } & \text { Laos } & \text { Tunisia } \\ \text { Bangladesh } & \text { Latvia } & \text { Turkmenistan } \\ \text { Belarus } & \text { Lebanon } & \text { Ukraine } \\ \text { Bolivia } & \text { Lithuania } & \text { United Arab Emirates } \\ \text { Bosnia and Herzegovina } & \text { Madagascar } & \text { Uruguay } \\ \text { Botswana } & \text { Malaysia } & \text { Uzbekistan } \\ \text { Brazil } & \text { Mauritania } & \text { Venezuela } \\ \text { Bulgaria } & \text { Mexico } & \text { Vietnam } \\ \text { Cambodia } & \text { Moldova } & \text { Yemen } \\ \text { Cameroon } & \text { Mongolia } & \text { Zambia } \\ \text { Chile } & \text { Morocco } & \text { Zimbabwe }\end{array}$




$\begin{array}{ll}\text { China } & \text { Mozambique } \\ \text { Colombia } & \text { Namibia } \\ \text { Costa Rica } & \text { Nicaragua } \\ \text { Cote d'Ivoire } & \text { Nigeria } \\ \text { Croatia } & \text { Oman } \\ \text { Dominican Republic } & \text { Pakistan } \\ \text { Ecuador } & \text { Panama } \\ \text { Egypt } & \text { Paraguay } \\ \text { El Salvador } & \text { Peru } \\ \text { Ethiopia } & \text { Philippines } \\ \text { Gabon } & \text { Poland } \\ \text { Georgia } & \text { Qatar } \\ \text { Ghana } & \text { Romania } \\ \text { Guatemala } & \text { Russia } \\ \text { Guinea } & \text { Saudi Arabia } \\ \text { Honduras } & \text { Senegal } \\ \text { Hungary } & \text { Serbia } \\ \text { India } & \text { South Africa } \\ \text { Indonesia } & \text { Sri Lanka } \\ \text { Iran } & \text { Sudan } \\ \text { Jamaica } & \text { Syria }\end{array}$

Appendix B. Variables' Definitions and Sources

\begin{tabular}{|c|c|c|}
\hline Variables & Definitions and Measurements & Sources \\
\hline $\begin{array}{c}\text { Human Development } \\
\text { Index (HDI) }\end{array}$ & $\begin{array}{l}\text { "A summary measure of average } \\
\text { achievement in key dimensions of } \\
\text { human development: a long and } \\
\text { healthy life, being knowledgeable and } \\
\text { have a decent standard of living. The } \\
\text { HDI is the geometric mean of } \\
\text { normalized indices for each of the three } \\
\text { dimensions." } \\
\text { "The health dimension is assessed using } \\
\text { life expectancy at birth, the education } \\
\text { dimension is measured using the mean } \\
\text { number of years of schooling for adults } \\
\text { aged } 25 \text { years and more, and expected } \\
\text { years of schooling for children of school } \\
\text { entering age. The standard of living } \\
\text { dimension is measured using the gross } \\
\text { national income per capita. The HDI } \\
\text { uses the logarithm of income to reflect } \\
\text { the diminishing importance of income } \\
\text { with increasing gross national income } \\
\text { (GNI). The scores for the three HDI } \\
\text { dimension indices are then aggregated } \\
\text { into a composite index using a } \\
\text { geometric mean. }\end{array}$ & $\begin{array}{l}\text { United Nations Development } \\
\text { Programme (UNDP) } \\
\text { http://hdr.undp.org/en/content/ } \\
\text { human-development-index-hdi }\end{array}$ \\
\hline
\end{tabular}




\begin{tabular}{|c|c|c|}
\hline Variables & Definitions and Measurements & Sources \\
\hline $\begin{array}{l}\text { Economic Complexity } \\
\text { Index }(\mathrm{ECI})\end{array}$ & $\begin{array}{l}\text { "The complexity of an economy is } \\
\text { related to the multiplicity of useful } \\
\text { knowledge embedded in it. Because } \\
\text { individuals are limited in what they } \\
\text { know, the only way societies can } \\
\text { expand their knowledge base is by } \\
\text { facilitating the interaction of individuals } \\
\text { in increasingly complex networks in } \\
\text { order to make products. We can } \\
\text { measure economic complexity by the } \\
\text { mix of these products that countries are } \\
\text { able to make." } \\
\text { Economic complexity, therefore, is } \\
\text { expressed in the composition of a } \\
\text { country's productive output and reflects } \\
\text { the structures that emerge to hold and } \\
\text { combine knowledge." }\end{array}$ & $\begin{array}{c}\text { OEC } \\
\text { https://oec.world/en/rankings/ } \\
\text { country/eci/ }\end{array}$ \\
\hline $\begin{array}{l}\text { Income Inequality } \\
\text { (GINI EHII) }\end{array}$ & $\begin{array}{c}\text { Estimated Household Income Inequality } \\
\text { Data Set (EHII) - is a global dataset, } \\
\text { derived from the econometric } \\
\text { relationship between UTIP-UNIDO, } \\
\text { other conditioning variables, and the } \\
\text { World Bank's Deininger \& Squire data } \\
\text { set. }\end{array}$ & $\begin{array}{l}\text { University of Texas Inequality } \\
\text { Project } \\
\text { https: } \\
\text { //utip.lbj.utexas.edu/data.html }\end{array}$ \\
\hline $\begin{array}{l}\text { Gender Inequality } \\
\text { Index (GII) }\end{array}$ & $\begin{array}{l}\text { The GII is an inequality index. It } \\
\text { measures gender inequalities in three } \\
\text { important aspects of human } \\
\text { development: reproductive health, } \\
\text { measured using maternal mortality } \\
\text { ratio and adolescent birth rates; } \\
\text { empowerment, measured using the } \\
\text { proportion of parliamentary seats } \\
\text { occupied by females and the proportion } \\
\text { of adult females and males aged } 25 \\
\text { years and older with at least some } \\
\text { secondary education; and economic } \\
\text { status, expressed as labor market } \\
\text { participation and measured using the } \\
\text { labor force participation rate of female } \\
\text { and male populations aged } 15 \text { years and } \\
\text { older. }\end{array}$ & $\begin{array}{c}\text { UNDP } \\
\text { http: } \\
\text { //hdr.undp.org/en/composite/GII }\end{array}$ \\
\hline $\begin{array}{l}\text { Fossil fuel energy } \\
\text { consumption (\% of } \\
\text { total energy } \\
\text { consumption) }\end{array}$ & $\begin{array}{l}\text { The percentage of total energy } \\
\text { consumption that comes from fossil } \\
\text { fuels, which consist of coal, oil, } \\
\text { petroleum, and natural gas products. }\end{array}$ & $\begin{array}{l}\text { UNDP environmental } \\
\text { sustainability }\end{array}$ \\
\hline $\begin{array}{l}\text { Renewable energy } \\
\text { consumption (\% of } \\
\text { total energy) }\end{array}$ & $\begin{array}{l}\text { The share of renewable energy in the } \\
\text { total final energy consumption. } \\
\text { Renewable sources include } \\
\text { hydroelectric, geothermal, solar, tides, } \\
\text { wind, biomass, and biofuels. }\end{array}$ & $\begin{array}{l}\text { UNDP environmental } \\
\text { sustainability }\end{array}$ \\
\hline
\end{tabular}




\begin{tabular}{|c|c|c|}
\hline Variables & Definitions and Measurements & Sources \\
\hline $\mathrm{CO}_{2}$ emissions $(\mathrm{kt})$ & $\begin{array}{l}\text { Carbon dioxide emissions are those } \\
\text { stemming from the burning of fossil } \\
\text { fuels and the manufacture of cement. } \\
\text { They include carbon dioxide produced } \\
\text { during the consumption of solid, liquid, } \\
\text { and gas fuels and gas flaring. }\end{array}$ & World Bank \\
\hline Unemployment & $\begin{array}{l}\text { Unemployment, total (\% of total labor } \\
\text { force) (national estimate). } \\
\text { Unemployment refers to the share of the } \\
\text { labor force that is without work but } \\
\text { available for and seeking employment. } \\
\text { Definitions of labor force and } \\
\text { unemployment differ by country. }\end{array}$ & World Bank \\
\hline $\begin{array}{l}\text { World Governance } \\
\text { Indicators (WGI) }\end{array}$ & $\begin{array}{l}\text { "Governance consists of the traditions } \\
\text { and institutions by which authority in a } \\
\text { country is exercised." } \\
\text { VA: Voice and accountability captures } \\
\text { perceptions of the extent to which a } \\
\text { country's citizens can participate in } \\
\text { selecting their government, as well as } \\
\text { freedom of expression, freedom of } \\
\text { association, and a free media. } \\
\text { PV: Political stability and absence of } \\
\text { violence measures the perceptions of the } \\
\text { likelihood of political instability and/or } \\
\text { politically motivated violence, including } \\
\text { terrorism. }\end{array}$ & $\begin{array}{c}\text { World Bank group } \\
\text { https://datacatalog.worldbank. } \\
\text { org/dataset/worldwide- } \\
\text { governance-indicators }\end{array}$ \\
\hline
\end{tabular}

\section{References}

1. Hausmann, R.; Hidalgo, C.A.; Bustos, S.; Coscia, M.; Chung, S.; Jemenez, J.; Simoes, A.; Yidirim, M.A. The Atlas of Economic Complexity; MIT Press: Cambridge, MA, USA, 2011.

2. Lapatinas, A. Economic complexity and human development: A note. Econ. Bull. 2016, 36, 1441-1452.

3. Murray, C.; Abraham, J.; Ali, M.; Alvarado, M.; Atkinson, C.; Baddour, L.; Bartels, D.; Benjamin, E.; Bhalla, K.; Birbeck, G.; et al. The State of US Health, 1990-2010. Burden of diseases, injuries, and risk factors. J. Am. Med. Assoc. 2013, 310, 591-608. [CrossRef] [PubMed]

4. Mokdad, A.H.; Ballestros, K.; Echko, M.; Glenn, S.; Olsen, H.E.; Mullany, E.; Lee, A.; Khan, A.; Ahmadi, A.; Ferrari, A.; et al. The State of US Health, 1990-2016. Burden of diseases, injuries, and risk factors among US States. J. Am. Med. Assoc. 2018, 319, 1444-1472. [CrossRef]

5. Hartmann, D.; Guevara, M.R.; Jara-Figueroa, C.; Aristarán, M.; Hidalgo, C.A. Linking economic complexity, institutions, and income inequality. World Dev. 2017, 93, 75-93. [CrossRef]

6. Constantine, C.; Khemraj, T. Geography, Economic Structures and Institutions: A Synthesis. Struct. Chang. Econ. Dyn. 2019, 51, 371-379. [CrossRef]

7. Gaye, A. Access to Energy and Human Development; Human Development Report Office, UNDP: New York, NY, USA, 2008.

8. Ferraz, D.; Moralles, H.F.; Campoli, J.S.; Ribeiro de Oliveira, F.C.; Rebelatto, D.A.D.N. Economic Complexity and human development: DEA performance measurement in Asia and Latin America TT-Complexidade economica e desenvolvimento humano: Uma Análise a Partir Do DEA. Gestão Produção 2018, 25, 839-853. [CrossRef]

9. Le Caous, E.; Huarng, F. Economic complexity and its effects on human development: Moderated by gender inequality and environmental sustainability. In Proceedings of the International Conference on Design with Intelligence and Humanity, Yunlin, Taiwan, 22-24 November 2019. 
10. Smit, S. Determinants of human development index: A cross-country empirical analysis. Munich Pers. RePEc Arch. 2016, 1-33. [CrossRef]

11. Sen, A. Public action and the quality of life in developing countries. Oxf. Bull. Econ. Stat. 1981, 43, $287-319$. [CrossRef]

12. Suri, T.; Boozer, M.; Ranis, G.; Stewart, F. Paths to success: The relationship between human development and economic growth. World Dev. 2011, 39, 506-522. [CrossRef]

13. Mustafa, G.; Rizov, M.; Kernohan, D. Growth, human development, and trade: The asian experience. Econ. Model. 2017, 61, 93-101. [CrossRef]

14. De la Prados Escosura, L. World Human Development: 1870-2007. Rev. Income Wealth 2013, 61, $220-247$. [CrossRef]

15. Stephan, K. Human Development Indices and Indicators. 2018 Statistical Update. 2018. Available online: http://hdr.undp.org/sites/default/files/2018_human_development_statistical_update.pdf (accessed on 2 March 2020).

16. Stanton, E. The Human Development Index: A History. PERI Working Papers. 2007. Available online: https://scholarworks.umass.edu/cgi/viewcontent.cgi?article=1101\&context=peri_workingpapers (accessed on 2 March 2020).

17. Saviotti, P.P.; Pyka, A. From necessities to imaginary worlds: Structural change, product quality and economic development. Technol. Forecast. Soc. Chang. 2013, 80, 1499-1512. [CrossRef]

18. Hausmann, C.A.; Hidalgo, S.; Bustos, Y.C. OEC: The Observatory of Economic Complexity. 2007, p. 350. Available online: https://oec.world/en/resources/data/ (accessed on 2 March 2020).

19. Hartmann, D. Economic Complexity and Human Development: How Economic Diversification and Social Networks Affect Human Agency and Welfare; Taylor and Francis: River Thames, UK, 2014. [CrossRef]

20. Hartmann, D.; Pyka, A. Innovation, Economic Diversification and Human Development Innovation. FZID Discussion Paper. 2013. Available online: https://www.econstor.eu/handle/10419/69738 (accessed on 2 March 2020).

21. Anand, S.; Sen, A. The income component of the human development index. J. Hum. Dev. 2000, 1, 83-106. [CrossRef]

22. Sen, A. Mortality as an indicator of economic success and failure. Econ. J. 1998, 108, 1-25. [CrossRef]

23. Sen, A. The possibility of social choice. Am. Econ. Rev. 1999, 89, 349-378. [CrossRef]

24. Mariano, E.B.; Sobreiro, V.A.; Rebelatto, D.A.D.N. Human development and data envelopment analysis: A structured literature review. Omega 2015, 54, 33-49. [CrossRef]

25. Ferraz, D.; Silveira, N.J.C.; Moralles, H.F.; Aparecida, D.; Pyka, A. An efficiency analysis of economic complexity and human development in 2013. In Proceedings of the 4th Responsible Management Education Research (RMER), Curitiba, Brazil, 14 September 2017.

26. Atlas of Economic Complexity; Growth Lab at the Harvard Univeristy. Available online: http://atlas.cid. harvard.edu/ (accessed on 2 March 2020).

27. Hausmann, R.; Hidalgo, C.A.; Bustos, S.; Coscia, M.; Chung, S.; Jimenez, J.; Simoes, A.; Yildirim, M.A. The Atlas of Economic Complexity: Mapping Paths to Prosperity; MIT Press: Cambridge, MA, USA, 2014; Volume 51. [CrossRef]

28. Hidalgo, C.A.; Hausmann, R. The building blocks of economic complexity. Proc. Natl. Acad. Sci. USA 2009, 106, 10570-10575. [CrossRef]

29. Mariani, M.S.; Vidmer, A.; Medo, M.; Zhang, Y.C. Measuring economic complexity of countries and products: Which metric to use? Eur. Phys. J. B 2015, 88, 293. [CrossRef]

30. Cristelli, M.; Gabrielli, A.; Tacchella, A.; Caldarelli, G.; Pietronero, L. Measuring the intangibles: A metrics for the economic complexity of countries and products. PLOS ONE 2013, 8, 1-20. [CrossRef]

31. Cristelli, M.; Tacchella, A.; Pietronero, L. The heterogeneous dynamics of economic complexity. PLoS ONE 2015, 10, 1-15. [CrossRef]

32. Albeaik, S.; Kaltenberg, M.; Alsaleh, M.; Hidalgo, C.A. Improving the economic complexity index. arXiv 2017, arXiv:1707.05826.

33. Beaudreau, B.C. On the emergence and evolution of economic complexity. Mod. Econ. 2011, 2, $266-278$. [CrossRef]

34. Utkovski, Z.; Pradier, M.F.; Stojkoski, V.; Perez-Cruz, F.; Kocarev, L. Economic complexity unfolded: Interpretable model for the productive structure of economies. PLoS ONE 2018, 13, 1-24. [CrossRef] 
35. Ferrarini, B.; Scaramozzino, P. Production complexity, adaptability and economic growth. Struct. Chang. Econ. Dyn. 2016, 37, 52-61. [CrossRef]

36. Antonelli, G.; Cappiello, G. Smart Development in Smart Communities; Taylor \& Francis: River Thames, UK, 2016. [CrossRef]

37. Saviotti, P.P.; Pyka, A.; Jun, B. Education, structural change and economic development. Struct. Chang. Econ. Dyn. 2016, 38, 55-68. [CrossRef]

38. Hartmann, D.; Jara-Figueroa, C.; Simoes, A.; Guevara, M.; Hidalgo, C.A. The structural constraints of income inequality in latin America. Integr. Trade 2016, 40, 70-85.

39. Lee, L.; Wong, P.K.; Chua, B.L.; Chen, J. Antecedents for Entrepreneurial Propensity: Findings from Singapore, Hong Kong and Taiwan. 2006. Available online: http://dx.doi.org/10.2139/ssrn.979049 (accessed on 2 March 2020).

40. Schwartz, B. The Paradox of Choice: Why More Is Less? Ecco: New York, NY, USA, 2004. Available online: https://wp.vcu.edu/univ200choice/wp-content/uploads/sites/5337/2015/01/The-Paradox-of-ChoiceBarry-Schwartz.pdf (accessed on 2 March 2020). [CrossRef]

41. Dabla-Norris, E.; Kochhar, K.; Ricka, F.; Suphaphiphat, N.; Tsounta, E. Causes and Consequences of Income Inequality: A Global Perspective; International Monetary Fund: Washington, DC, USA, 2015.

42. Corak, M. Income Inequality, Equality of Opportunity, and Intergenerational Mobility. J. Econ. Perspect. 2013, 27, 79-102. [CrossRef]

43. Rajan, R.G. Fault Lines: How Hidden Fractures Still Threaten the World Economy; Princeton University Press: Princeton, NJ, USA, 2010.

44. Huarng, F.; Le Caous, E. Economic Complexity, human development, and the mediating role of income inequality. In Proceedings of the 15th International Conference on Knowledge-Based Economy and Global Management, Tainan City, Taiwan, 7-8 November 2019.

45. Levy, F.; Murnane, R.U.S. Earnings levels and earnings inequality: A review of recent trends and proposed explanations. J. Econ. Lit. 1992, 30, 1333-1381. [CrossRef]

46. Katz, L.F.; Murphy, K.M. Changes in relative wages, 1963-1987: Supply and demand factors. Q. J. Econ. 1992, 107, 35-78. [CrossRef]

47. Card, D.; Dinardo, J.E. Skill biased technological change and rising wage inequality: Some Problems and puzzles. J. Labor Econ. 2002, 20, 733-783. [CrossRef]

48. Violante, G.L. Skill-biased technical change. In The New Palgrave Dictionary of Economics; Palgrave Macmillan: London, UK, 2008; pp. 520-523. [CrossRef]

49. Berman, E.; Bound, J.; Machin, S. Implications of Skill-biased technological change: International evidence. Q. J. Econ. 1998, 113, 1245-1279. [CrossRef]

50. Weiss, M. Skill-biased technological change: Is there hope for the unskilled? Econ. Lett. 2008, 100, 439-441. [CrossRef]

51. Moran, D.D.; Wackernagel, M.; Kitzes, J.A.; Goldfinger, S.H.; Boutaud, A. Measuring sustainable development-Nation by nation. Ecol. Econ. 2008, 64, 470-474. [CrossRef]

52. Hák, T.; Moldan, B.; Dahl, A.L. Sustainablity Indicators: A Scientific Assessment; Island Press: Washington, DC, USA, 2007.

53. Pîrlogea, C. The human development relies on energy. Panel data evidence. Procedia Econ. Financ. 2012, 3, 496-501. [CrossRef]

54. Marin, C.; Studies, E.; Ramona, C.M.; Haret, S. Economic growth sustaining under environmental sustainability and human development. A global challenge. J. Knowl. Manag. Econ. Inf. Technol. 2012, 2, 220-234.

55. Gelard, P.; Abdi, A. Evaluating the effect of gender inequality on economic growth in countries with high human development index. Eur. Online J. Nat. Soc. Sci. Spec. Issue New Dimens. Econ. 2015, 4, 1714-1724.

56. Anand, S.; Sen, A. Gender Inequality and Human Development: Theories and Measurement; United Nations Development Programme: New York, NY, USA, 1995.

57. Stoet, G.; Geary, D.C. A simplified approach to measuring national gender inequality. PLoS ONE 2019, 14, e0205349. [CrossRef]

58. Available online: https://oec.world/en/rankings/country/eci/ (accessed on 2 March 2020).

59. Woltman, H.; Feldstain, A.; MacKay, J.C.; Rocchi, M. An introduction to hierarchical linear modeling. Tutor Quant. Methods Psychol. 2012, 8, 52-69. [CrossRef] 
60. Meinck, S.; Vandenplas, C. The Relationship between the Sample Sizes at Each Level of a Hierarchical Model and the Precision of the Outcome Model; IERI Monograph Series; IERI: Hamburg, Germany, 2012.

61. Kreft, I.; De Leeuw, J. Introduction to Multilevel Modelling; Sage Publications: London, UK, 1998.

62. Turnham, D. The Employment Problem in Less Developed Countries. A Review of Evidence; Development Centre of the Organisation for Economic Co-Operation and Development: Paris, France, 1971; Volume 1.

63. Costa, L.; Rybski, D.; Kropp, J.P. A human development framework for $\mathrm{CO}_{2}$ reductions. PLoS ONE 2011, 6 , e29262. [CrossRef]

64. Rybski, D.; Costa, L.; Kropp, J.P. Correlations between human development and $\mathrm{CO}_{2}$ emissions: Projections and implications. In AGU Fall Meeting Abstracts; Potsdam Institute for Climate Impact Research: Potsdam, Germany, 2013.

65. Castañeda, G.; Chávez-juárez, F. The Incidence of Culture, Governance and Economics on the Countries' Development through an Analysis of Coupled Networks. World Development Report. 2017. Available online: http://documents.worldbank.org/curated/en/618201487589776878/World-development-report2017-the-incidence-of-culture-governance-and-economics-on-the-countries-development-through-ananalysis-of-coupled-networks (accessed on 2 March 2020).

66. Human Development Report Office. Human Development Report 2016 Human Development for Everyone; Human Development Report Office, UNDP: New York, NY, USA, 2016; ISBN 978-92-1-060036-1.

67. Antonelli, C. Technological congruence and the economic complexity of technological change. Struct. Chang. Econ. Dyn. 2016, 38, 15-24. [CrossRef]

(C) 2020 by the authors. Licensee MDPI, Basel, Switzerland. This article is an open access article distributed under the terms and conditions of the Creative Commons Attribution (CC BY) license (http://creativecommons.org/licenses/by/4.0/). 